\title{
Evaluation of lateral load pattern in pushover analysis
}

\author{
S. I. Javadein ${ }^{1} \&$ R. Taghinezhad ${ }^{2}$ \\ ${ }^{I}$ Department of Civil Engineering, Islamic Azad University, \\ Bandar Anzali, Iran \\ ${ }^{2}$ Department of Civil Engineering, Islamic Azad University, \\ Torbat Heydariye, Iran
}

\begin{abstract}
The objective of this study is to evaluate the performance of the frame structures for various load patterns and a variety of natural periods by performing pushover and nonlinear dynamic time history analyses. 3, 5, 7, 9 and 13-story moment steel frame structures are used in the analyses and the load distributions for pushover analyses are chosen as triangular, IBC $(\mathrm{k}=2)$ and rectangular. These frames have five different natural periods. Even though the nonlinear dynamic time history analysis is the best way to compute seismic demands, FEMA-356 and ATC-40 proposes the use of nonlinear static procedure or pushover analysis. The five frame structures have been analyzed using the nonlinear program SAP2000. This paper is also intended to compare the results of pushover and nonlinear dynamic time history analyses. To evaluate the results from the pushover analyses for three load patterns and also five natural periods, nonlinear dynamic time history analyses are performed. Earthquake ground motions recorded at 3 stations during various earthquakes are used in the analyses. The ground motion records used in this study include TABAS, NAGHAN and ELCENTRO. Pushover and nonlinear time history analyses results are compared to choose the best load distribution for a specific natural period for this type of frame structure.
\end{abstract}

Keywords: pushover analysis, nonlinear time history, load patterns, momentresisting frame. 


\section{Introduction}

Only the life safety and collapse prevention in general earthquake resistant design phenomena are explicitly prevented in seismic design codes. The design is generally based on evaluating the seismic performance of structures. It is required to consider inelastic behavior while evaluating the seismic demands at low performance levels. FEMA-356 [1] and ATC-40 [2] use pushover analysis as nonlinear static analysis but nonlinear time history analysis has more accurate results on computing seismic demands. The purposes in earthquake-resistance design are:

(a) to prevent non-structural damage in minor earthquakes, which may occur frequently in life time.

(b) to prevent structural damage and minimize non-structural damage in moderate earthquakes which may occur occasionally.

(c) to prevent collapsing or serious damage in major earthquakes which may occur rarely. Designs are explicitly done only under the third condition.

The objective of this study is to evaluate the performance of the frame structures for various load patterns and variety of natural periods by performing pushover and nonlinear dynamic time history analyses. 3, 5, 7, 9 and 13-story moment steel frame structures are used in the analyses and the load distributions for pushover analyses are chosen as triangular (IBC, k=1), (IBC, k=2) and rectangular, where $\mathrm{k}$ is the an exponent related to the structure period to define vertical distribution factor IBC [3]. The five frame structures have been analyzed using nonlinear program SAP2000 [4] and the results have been compared by recorded response data. Both nonlinear static pushover analysis and nonlinear dynamic time history analysis are performed. The correlations between these nonlinear analyses are studied. The performance of the buildings subjected to various representative earthquake ground motions is examined. Finally, pushover and nonlinear time history analyses results are compared to choose the best load distribution (pattern) for specific natural period for these types of steel moment frame structures.

\section{Ground motion data}

The nonlinear response of structures is very sensitive to the structural modeling and ground motion characteristics. Therefore, a set of representative ground motion records that accounts for uncertainties and differences in severity, frequency and duration characteristics has to be used to predict the possible deformation modes of the structures for seismic performance evaluation purposes. For this study, it is considered as 3 different data used in the nonlinear dynamic time history analyses, given in the Table 1. The peak ground accelerations are in the range 0.348 to $0.722 g$, where $g$ is acceleration due to gravity. 
Table 1: $\quad$ Ground motion data used in the analyses.

\begin{tabular}{|c|c|c|}
\hline Record & Duration & Pga \\
\hline NAGHAN & 5.04 & $0.722 \mathrm{~g}$ \\
\hline TABAS & 25.04 & $0.933 \mathrm{~g}$ \\
\hline ELCENTRO & 53.8 & $0.348 \mathrm{~g}$ \\
\hline
\end{tabular}

\section{Description of the frame structure}

Four steel moment frames with 3, 5, 7, 9 and 13-story were utilized to cover a broad range of fundamental periods. The moment steel frame structures are shown in Figure 1. The case study frames were designed for the AISC-ASD2001 [5] and Iranian 2800 Code-ver.3 [6]. Two dimensional models of case study frames were prepared using SAP2000 considering the necessary geometric and strength characteristics of all members that affect the nonlinear seismic response. Rigid floor diaphragms were assigned at each story level and the seismic mass of the frames were lumped at the mass center of each story. Gravity loads consisting of dead loads and $25 \%$ of live loads were considered in pushover and nonlinear time history analyses. The columns are assumed as fixed on the ground. Yield strength of the steel reinforcements is $2400 \mathrm{~kg} / \mathrm{cm}^{2}$. Also the cross section of all beams and columns in these frames are IPE and IPB-shapes respectively. Tree vibration analyses were performed to determine elastic periods and mode shapes of the frames. The dynamic properties of the case study frames are summarized in Table 2.

Sap length in all

structures $=4 \mathrm{~m}$

Story height in $=3.2 \mathrm{~m}$

$\mathrm{DL}=3200 \mathrm{~kg} / \mathrm{m}$

$\mathrm{LL}=800 \mathrm{Kkg} / \mathrm{m}$
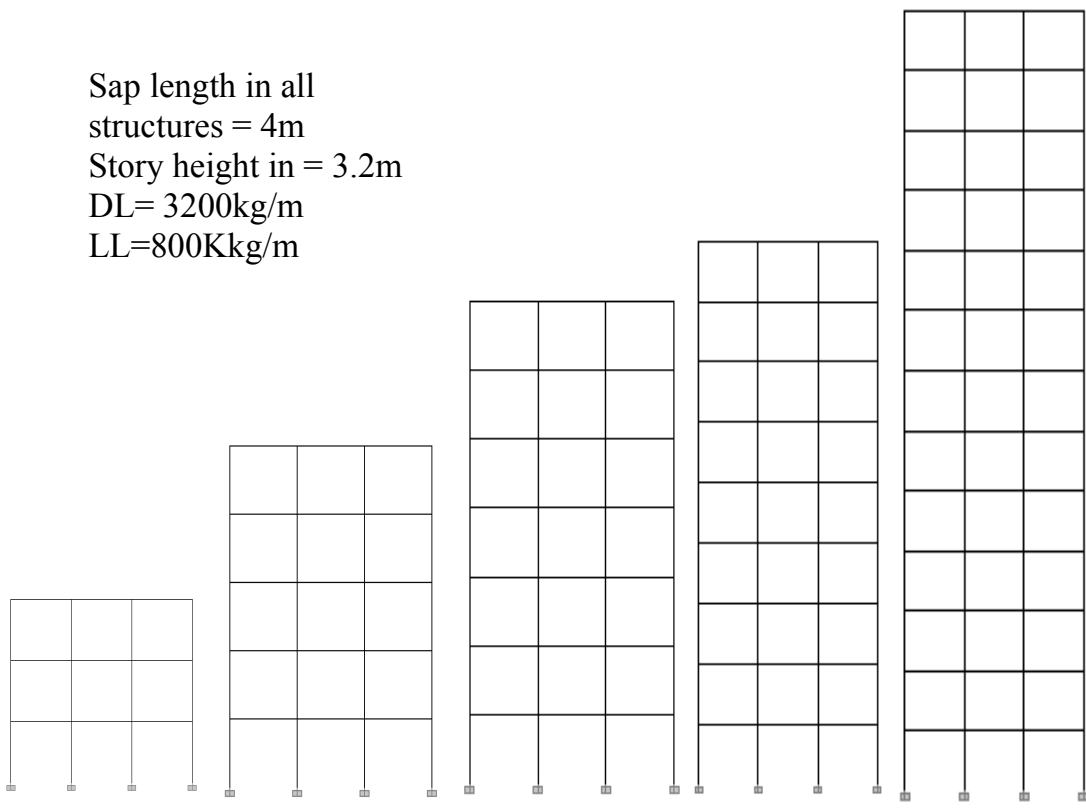

Figure 1: Diagram of analyzed 3, 5, 7, 9 and 13-story moment steel frames. 
The first, second and third natural periods of the structures are given in Table 2.

Table 2: $\quad$ Dynamic properties of case study frames.

\begin{tabular}{|c|c|c|c|}
\hline \multirow{2}{*}{ Frame } & \multicolumn{3}{|c|}{ Period (sec.) } \\
\cline { 2 - 4 } & T1 & T2 & T3 \\
\hline 3 Story & 1.07 & 0.40 & 0.23 \\
\hline 5 Story & 1.34 & 0.52 & 0.30 \\
\hline 7 Story & 1.57 & 0.63 & 0.37 \\
\hline 9 Story & 2.58 & 0.82 & 0.45 \\
\hline 13 Story & 2.98 & 0.88 & 0.50 \\
\hline
\end{tabular}

\section{Nonlinear static pushover analysis of frame structures}

The static pushover procedure has been presented and developed over the past twenty years by various researches. The method is also described and recommended as a tool for design and assessment purpose for the seismic rehabilitation of existing building and represents a main component of the Spectrum Capacity Analysis Method (ATC-40) [2]. It is clear from recent discussion that this approach is likely to be recommended in future codes.

For low performance levels, to estimate the demands, it is required to consider inelastic behavior of the structure. Pushover analysis is used to identify the seismic hazards, selection of the performance levels and design performance objectives. In pushover analysis, applying lateral loads in patterns that represent approximately the relative inertial forces generated at each floor level and pushing the structure under lateral loads to displacements that are larger than the maximum displacements expected in design earthquakes (Li [7]). The pushover analysis provides a shear vs. displacement relationship and indicates the inelastic limit as well as lateral load capacity of the structure. The changes in slope of this curve give an indication of yielding of various structural elements. The main aim of the pushover analysis is to determine member forces and global and local deformation capacity of a structure. The information can be used to assess the integrity of the structure. After designing and detailing the moment steel frame structures, a nonlinear pushover analysis is carried out for evaluating the structural seismic response. For this purpose the computer program SAP2000 has been used. Three simplified loading patterns; triangular (IBC, $\mathrm{k}=1), \mathrm{IBC}(\mathrm{k}=2)$ and rectangular, where $\mathrm{k}$ is an exponent related to the structure period to define vertical distribution factor, are used in the nonlinear static pushover analysis of 3, 5, 7, 9 and 13-story steel frame structures. Load criteria are based on the distribution of inertial forces of design parameters. The simplified loading patterns as uniform distribution, triangular distribution and IBC distribution. These loading patterns are the most common loading parameters. Vertical distribution of seismic forces: 


$$
\begin{array}{r}
F_{x}=C_{v x} V \\
C v x=\frac{w_{x} h_{x}^{k}}{\sum_{i=1}^{n} w_{i} h_{i}^{k}}
\end{array}
$$

$C v x=$ Vertical distribution factor

$V=$ Total design lateral force or shear at the base of structure.

$w i$ and $w x=$ The portion of the total gravity load of the structure $h i$.

$h x=$ The height from the base.

$k=$ An exponent related to the structure period.

In addition these lateral loadings, frames are subjected live loads and dead weights. P- $\Delta$ effects have been taken into the account during the pushover analyses. The lateral force is increased for 3, 5, 7, 9 and 13-story steel frames until the structures collapsed. Beam and column elements are used to analyze the frames. The beams are assumed to be rigid in the horizontal plane. Inelastic effects are assigned to plastic hinges at member ends. Strain-hardening is neglected in all elements. Bilinear moment-rotation relationship is assumed for both beam and column members. The results of the pushover analyses in 3, 5, 7, 9 and 13-story steel frames are presented in Figures 2 and 3 respectively.
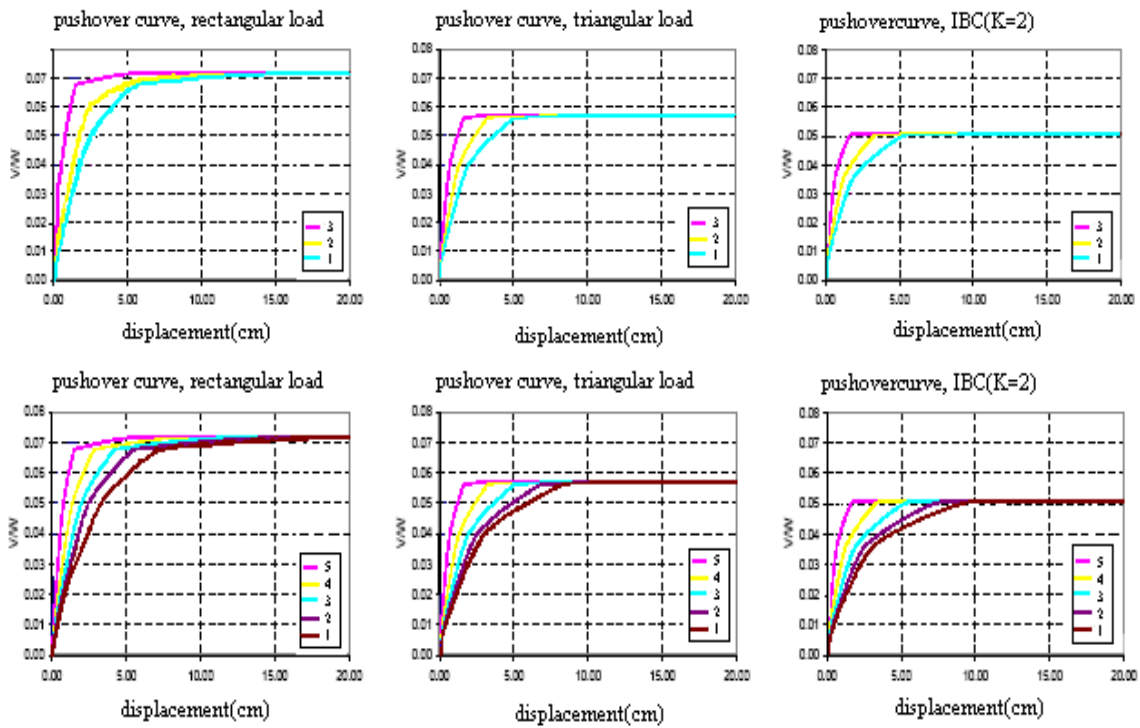

Figure 2: $\quad$ Pushover curves of 3 and 5-story steel frame for three different load patterns. 

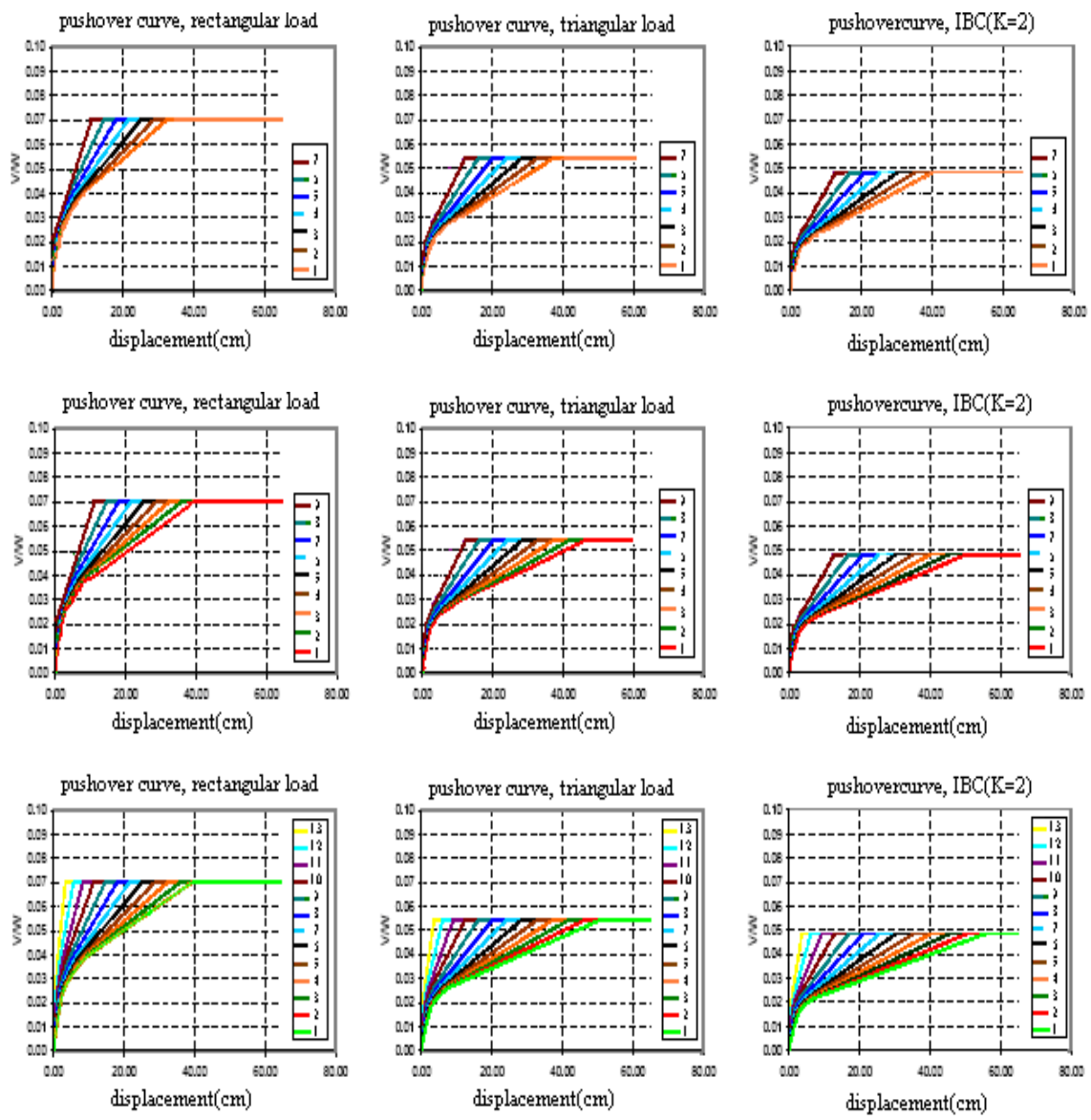

Figure 3: $\quad$ Pushover curves of 7, 9 and 13-story steel frame for three different load patterns.

The pushover curves are shown for three distributions, and for each frame structures. The curves represent base shear-weight ratio versus story level displacements for uniform, triangular and IBC load distribution. Shear $V$ was calculated by summing all applied lateral loads above the ground level, and the weight of the building $W$ is the summation of the weights of all floors. Beside these, these curves represent the lost of lateral load resisting capacity and shear failures of a column at the displacement level. The changes in slope of these curves give an indication of yielding of various structural elements, first yielding of beam, first yielding of column and shear failure in the members. By the increase in the height of the frame structures, first yielding and shear failure of the columns is experienced at a larger roof displacements and rectangular distribution always give the higher base shear-weight ratio comparing to other load distributions for the corresponding story displacement (horizontal displacement). 


\section{Nonlinear dynamic time history analysis of frame structures}

After performing pushover analyses, nonlinear dynamic time history analyses have been employed to the five different story frame structures. These frames are subjected live and dead weights. Also P- $\Delta$ effects are under consideration as in pushover analysis. For time history analysis $\mathrm{P}-\Delta$ effects have been taken into the account. Finite element procedure is employed for the modeling of the structures during the nonlinear dynamic time history analyses. SAP2000 has been used for nonlinear time history analysis and modeling. The model described for pushover analyses has been used for the time history analyses. Mass is assumed to be lumped at the joints. The frames are subjected to 3 earthquake ground motions, which are recorded during TABAS, NAGHAN and ELSENTRO for the nonlinear dynamic time history analyses (Figure 4).

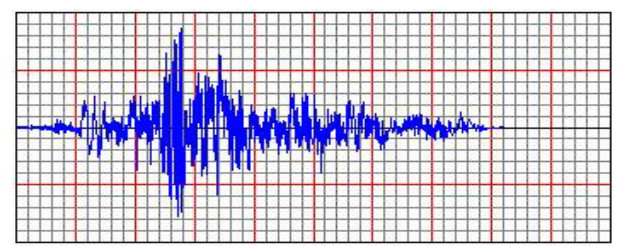

a) TABAS

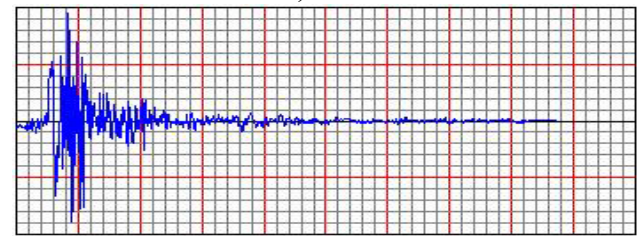

b) NAGHAN

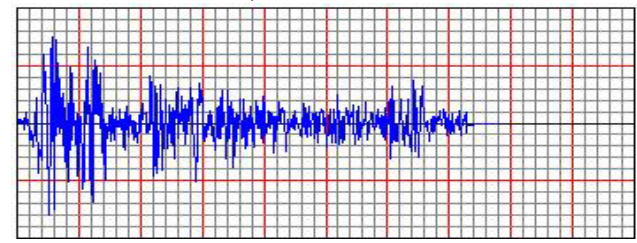

c) ELCENTRO

Figure 4: Acceleration-time histories of ground motion records.

These data are from different site classes as I, II, III and IV. The selected earthquake ground motions have different frequency contents and peak ground accelerations. The ground motion data are chosen from near-field region to evaluate the response of the frame structures in this region and comparison of them with pushover analyses results.

The results of nonlinear time history analysis for 3, 5, 7, 9 and 13-story steel frame structure are presented in Figure 5. 


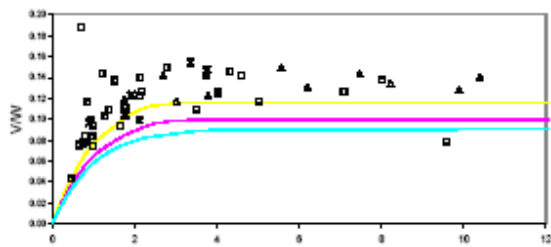

a) 3-story

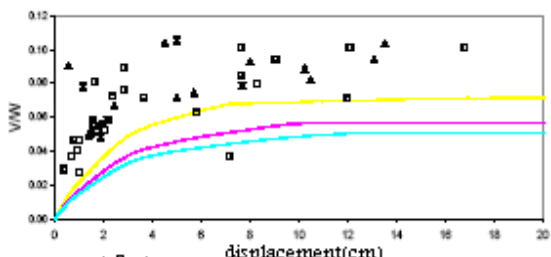

c) 7-story

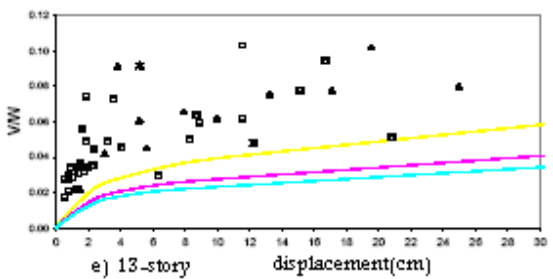

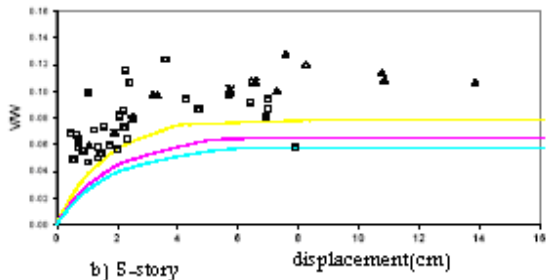

b) S-story

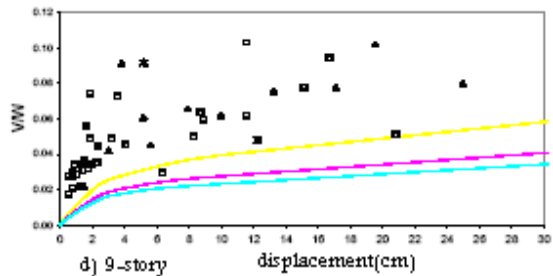

d) $9-5$ toty

Rectangtular a I and II site

- Triangular $\cdot C$ site

- IBC $\quad$ D site

Figure 5: Pushover and nonlinear time history results of 3, 5, 7, 9 and 13-story.

Pushover and nonlinear time history analyses results are compared to for specific natural period for five different frame structures and for each load distributions; rectangular, triangular and IBC $(\mathrm{k}=2)$.

\section{Conclusion}

After designing and detailing the moment steel frame structures, a nonlinear pushover analysis and nonlinear dynamic time history analysis are carried out for evaluating the structural seismic response for the acceptance of load distribution for inelastic behavior. It is assumed for pushover analysis that seismic demands at the target displacement are approximately maximum seismic demands during the earthquake. According to Figures 2 and 3, for higher story frame structures, first yielding and shear failure of the columns is experienced at the larger story displacements and rectangular distribution always give the higher base shearweight ratio comparing to other load distributions for the corresponding story displacement. As it is presented in Figure 5, nonlinear static pushover analyses for IBC $(\mathrm{k}=2)$, rectangular, and triangular load distribution and nonlinear time history analyses results for the chosen ground motion data (all of them are nearfield data) are compared. Pushover curves do not match with nonlinear dynamic time history analysis results especially for higher story moment steel frame structures (9 and 13-story frame structures). The pushover analyses results for 
rectangular load distribution estimate maximum seismic demands during the given earthquakes more reasonable than the other load distributions, IBC $(\mathrm{k}=2)$, and triangular.

\section{References}

[1] FEMA (2000b). "Prestandard and Commentary for the Seismic Rehabilitation of Buildings", Report FEMA-356, Federal Emergency Management Agency, Washington, DC, U.S.A.

[2] ATC-40, "Seismic evaluation and Retrofit of Concrete Buildings", Vol.1, Applied Technology Council, Redwood City, CA, 1996.

[3] IBC, International Building Code, International Conference of Building Officials, Whittier, California, 2000.

[4] Computers and Structures Inc. (CSI), SAP2000 Three Dimensional Static and Dynamic Finite Element Analysis and Design of Structures V7.40N, Berkeley, California.

[5] AISC, Manual of Steel Construction: Load and Resistance Factor Design, 3rd Edition, American Institute of Steel Construction, Chicago, IL, 2001.

[6] Iranian Code of Practice for Seismic Resistant Design of Building, Standard No. 2800-5, 3rd Edition, Building and Housing Research Center, 2005.

[7] Li, Y.R. Non-Linear Time History And Pushover Analyses for Seismic Design and Evaluation. PhD Thesis, University of Texas, Austin, TX. 1996. 